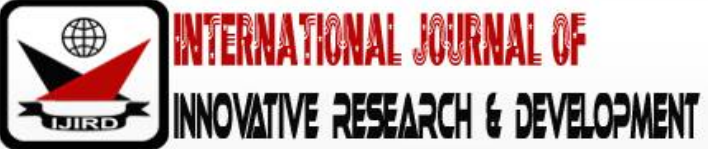

ISSN 2278 - 0211 (Online)

\section{Contextualizing the Parable of the Prodigal Son within The African Cultural Setting}

\author{
Dr. Jaja Bethel Onyechere \\ Lecturer, Department of Religious and Cultural Studies, \\ University of Port Harcourt, Nigeria
}

\begin{abstract}
:
The paper on contextualizing the Parable of the Prodigal Son within the African cultural setting in Luke 15:11-32, has these as the objectives; to critically examine why the cultural context was left out in the story, to also showcase the benefits derivable from contextualizing this parable and further to prove that every culture has something to offer its people even in this parable. The methodology adopted includes critical textual and hermeneutical analysis of the text among others. The result revealed that there are lots of good lessons to derive from both the Jewish and the African cultural impute in this story. Suppressing cultural impute may amount to denying the audience from benefiting from certain aspect of the teaching.
\end{abstract}

Keyword: Contextualizing, prodigal son's, cultural context

\section{Introduction}

Certain gospel messages never met its original goals within the African context because it has never been addressed in the unique format and characteristics of the African attire.

The Bible writers out of their goodwill reflected the culture of the Jews people to their best of knowledge which invariably was their primary audience. The writers did their work to meet the immediate needs of their audience and to their understanding. The message they communicated got to them with passion and compassion. Additionally, the Gospel message came to the people with vigor, with encouragement, with hope, with love and with care.

The Jews by religion were Judaizes, and were knowledgeable on the Old Testament laws and the Torah. But with the advent of the New Testament gospel, they came into a new life partnership. Although, their knowledge of the law was unique but the impact of the gospel met their long messianic expectation and their desire appears to have been met.

The contrary is what we have in the African setting, where there is nothing reflective of the African culture and languages especially in the parable stories in gospel. Yet, Africans are good lovers of religion especially Christianity which they love with passion. This was demonstrated in the rate at which Christianity grew especially south of the Sahara Desert.

The story of children misbehavior is an old long issue that dates back to the time of Noah, Just some little time after the flood. Children were known to exhibit several unwanted attitudes, among this ill behaviour ranges from drunkenness, immoral lifestyle, etc.

The issue of bad behaviour cuts across different tribes, cultures, religions and faith. There is no religion or culture or tribe without one form of evil or the other.

The story of the Prodigal son is only found in Luke 15. Although scholars tend to speculate that Luke wrote this story because he was a gentile and no Jew could have written such a story.

Jesus told the story during when He was teaching His audience. He used a trilogy of Parabolic analogical arguments to react to the legalistic accusation advanced to Him by the Pharisees, where He was being accused of associating with sinners. The main character of the parable is the wayward son and therefore the story is often called, "The Prodigal Son". The next prominent character in the story is the Prodigal father who granted the son's request.ii

This story could also be likened to the children of our day that could easily be influenced through association with their peer groups, friends and lots of others. These are done at the detriment of their parents.

Children learn lots of evil things as they associate with friends, relations etc. that they do not know too well. Lots of children have entered their early grave due to bad companies; lots of others have been jailed for just following a friend to an unknown destination.

It is this unwanted influence which children are involved and the none inclusion of the cultural aspect of the story that attracted the interest for the researcher.

It is true that every culture has something to either explain or teach the people. This none inclusion of the cultural background into the story has certainly robbed the original hearers and more so the Africans certain lessons they could have learnt within the context of the parable.

The objectives of this paper are as follows; 
- To critically examine why the cultural context was not part of the story

- To showcase the benefits of contextualizing this parable

- To also show that every culture has something to offer to its people including this parable.

The methodology adopted for this study include critical textual methods and hermeneutical analysis of the text, while other additional materials were sourced from journals, Bibles, Books, the print media, internet and through personal interviews which serve as the primary source.

Theoretical Framework

This study adopted Adolf Julicher approach to interpretation of parable which was contrary to the existing norm after the New Testament times where allegorical method was in use $e^{\text {iii. }}$

Definition of key words

By definition, Contextualization is the application of Biblical truths to the circumstances and situations to be experienced in a target culture. While the contextualized message of the gospel just described addresses the matter of beliefiv

Culture could be seen as a shared beliefs and values of group: the beliefs, customs, practices, and social behavior of a particular nation or people

From Taber point of view "culture" is focus on the subjective side of human experience-on what "goes on in people's heads;" on the different "sets of ideas"v that shape how they live in the world, what they claim to know. how they respond to life's challenges, and what they believe to be good, true. Valuable or noble. Culture is the full repertoire of what is learned from and shared with others in a given society.vi

\section{Discussion/ Exegesis}

A parable is a short fictitious story that illustrates a moral attitude or a religious principle. It comes from the Greek

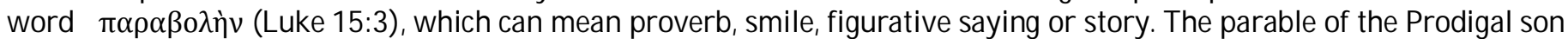
is the third of three parables; Jesus told in Luke 15 in response to the grumblings of the religious leaders Luke 15:2.vii This is because they were associating Jesus with sinners and tax collectors, the first of this triad of parables is the parable of the lost sheep (Luke 15:3-7) which called a pastoral metaphor, the second the parable of the lost coin Luke 15: 8-10 features as a domestic illustration. Both of these parables serve as an introduction to the parable of the prodigal son. Although, this parable followed the general structure of the first two but however differs as it expands on it.viii

The first two parables end with a direct comparison of the rejoicing of the characters in the parable of the rejoicing in heaven (Luke 15; 7,10). The third also exhibits rejoicing at the return of the prodigal son, but was resented by the older son over the bother that came back after squandering his property.

The voice of Jesus dominated the narrative, shifting and evaluating all other speech.

\subsection{The Prodigal Son Request Unheard of from 15:1-12}

To ask one's father for ones share of inheritance early was unheard of in antiquity, this could also be said to mean, "Father, I wish you were already dead". Such a request would not go well in their society (even in our today world) which stresses obedience to one's father which if violated will amount to a serious act of rebellion in which case the father will be left with no other option than to beat him thoroughly (Deuteronomy 21:18-21)

Furthermore, that the father granted the request means that most of the hearers will not identify with the father in this parable. They may think of him as been stupid and one who over pamper such an irresponsible son.

Prodigal Request a dishonor to the father

In the application of Adolf Julicher concept in the interpretation of parables, the issue presented here was one showing a depraved sonix who asked his father for his inheritance while the father was bubbling in good health. This act essentially implying that he wishes his father was dead (Luke15:12). Such a request would dishonor the father and also would sever the son from the family as well as from the community at large. (Although, the father granted the foolish request of his son, however, this will amount to putting him in a serious security risk according to the Jewish customary laws.)

\subsection{Jewish Cultural Position on Property Ownership}

Jewish law did permit fathers to determine which properties or assets (especially land) that would go to their children before they die; however, they would take possession only on the death of their father. The father remains the crown agent and manager and received the land's profits until death. In the case of this story, the respective son knows what belong to each of them. ${ }^{x}$

\subsection{Jewish Culture on Heritage and African Culture}

The young man Jesus spoke about was a born Jew within a core Hebrew society. The Jewish had laws governing family estates from one generation to another. These laws were created to keep their lands from leaving the family heritage. The young man by his behaviour, had no respect for the Jewish laws or his father. The request made the younger son to be above his elder brother puts him as a selfish person.

Further to the context of the Jewish culture, the fifth commandment which states, "Honor your father and mother" this law was very important and a governing law. Therefore, any son that demanded what the younger son did would be dishonored by his father and the son would be slapped across the face, publicly by the father."xi 


\subsection{Foolishness Leads to Cultural Embarrassment}

In this story, the country which the younger son went to was not mentioned; but rather called "far country". It is also suggested that distant lands in their time refer to the "Gentile country"xii

The Jewish culture would never associate itself with Gentile person; and for this Jewish boy to live with Gentiles was the worst action he took. This invariably means dishonoring his father, but also his cultural heritage and faith.xii

\subsection{The Turning Point in the Prodigal Son's Journey}

When after all the avenues for the prodigal son was exhorted, he gradually came to his senses. He recounted to himself the number of servants his father has preferred to be one of them instead of starving because of hunger. Therefore, the son was ready to walk away from his evil ways and was ready to submit himself to his father's authority.

As the prodigal son begins his journey back to his father's home, by their culture, it would be expected for his father to refuse to meet with him face to face. The father would be expected to disgrace the son in front of the whole village, as the son had done him. According to the Mosaic Law the son would be put to death by stoning for dishonoring his father or mother. xiv Therefore, the public display of shame was a price compared to the other option. While the prodigal son walked a long way home ward with the thought of the punishment that he would be greeted with on his arrival at his father's home.

\subsection{The Father's Reaction, Defense and Protection}

Although his prodigal son has gotten his inheritance and parted with his kindred, his community unto an unknown land but his father's eyes was on the road looking with expectation that he will see him again.

It was believed that the father spotted his son during the day light or the father couldn't see him "a great way off". Therefore, the community was busy with activities during the incident.

Then came the faithful day, according to verse 20, "But when he was still a great way off, his father saw him and had compassion, and ran and fell on his neck and kissed him."

The father's action averted the communal ceremony that could have cut off the son from being a member of their community. According to Baileyxv "If a Jewish son lost his inheritance among the Gentile and returns home, the community could perform a ceremony, called the "Kezazah". They would break a large pot in front of him and yell, "You are now cut off from your people". The community would totally reject him.xvi The father runs and put himself in a shameful situation, in an effort to get his son before he enters the community, so that his son does not experience the shame and humiliation of their tauntry and rejection. The action of the father saved his son from the "Kezazah" ceremony xvii

\section{The Art in the African Context}

The Gospel message as was presented to the Africans still wear foreign attire, in its written form and in its demonstration. This has created a big problem with many unanswered questions. According to Hesselgravel, xviii to solve some of the problems people are battling with especially Africans, because it is still being served in a westernized cup, while by right the gospel is primarily a message that needs to be communicated as effectively as possible.

In his bid to help address the African problem of contextualization of the gospel, Donald Carsonix observed that contextualizers need to identify those parts of the Bible that do not reflect a particular culture of the people and give attention to it, in this case the parable of the prodigal son.

Furthermore, Stabell ${ }^{\mathrm{xx}}$ noticed that taking culture seriously is a means through which God reveals Himself to His people and also shows the weakness in the gospel message being presented. John Mbitexxi in his own opinion shows that contextualization is that process of teaching scripture with an understanding and the appreciation of Africa thoughts and beliefsxxii

Africans value their culture and tradition, because this provides a unique identity in their relationships and for the future with regards to one's status in the society.

Yes, it is true that the Bible is God's inspiration, which no one quarrels about that but it was physically designed in human cultural attire. Therefore, interpreting it without contextualization can cause some cultural gap. This is actually the business of this paper to fill in the gap created as a result of not putting the gospel within the cultural setting especial in the African context.

To put contextualization in sequence within African setting, Abugurimxxiii states that contextualization deals with the act of interpreting and applying the Biblical meanings to the African situation without the bible losing its original and universal meaning.

There are numerous cases at hand that the translators restricted their knowledge and information to only the culture of the Bible land. There has not been any attempt at reflecting the African cultural input into any of the translated gospel versions in Africa.

A major case at hand is how the African accepted Jesus teaching in Luke 15:11- 32. In the African context, it is impossible for a son to request for an inheritance while his father is alive. The son will either be cursed, by the father or by some other family members. However, if the father eventually decides to do otherwise, that will amount to that being the end of his relationship with his son. But if for whatever the foolish son returns back, there will be no celebration at all for him.xxiv The Bible writers did not observe that the prodigal son shamefully returned to his father after a failed mission.

Furthermore, if this incident happened like in Ethiopian community, the foolish son wound is killed secretly to prevent their community from being cursed by other communities.xxv A better understanding is needed to help these people to come to terms with the teaching of the Bible. This is part of what this research is advocating for. 
Another wordy example is what is obtained in the Bamasaabe tribe of Eastern Uganda. The custom requires that they prepare every young man for circumcision at the age of eighteen, to avoid any rebellious attitude or disobedience from their young men.xvi Again this is not in agreement with the teaching of the Bible.

Similarly, in Rivers state of Nigeria, Among the Abuah people, pregnant mothers are circumcised on the seventh month, this is to prevent them from suffering from unwanted death throughout the pregnancyxxvii. In a similar vein in their neibourhood of Oduah this occasion is usually celebrated all throughout the nightxxviii.

There are lots of other issues which have been never addressed. These include;

- The use of English wine and Bread for communion. This has lingered without finding a replacement within the African setting.

- There are lots of translation problems that certain language groups prefer toretain English names in their Bible, example like Angel or heaven in Ibibo Bible. This language among others are yet to come out with appropriate word substitute that reflects the meaning and the purpose in their dilate.

\section{Benefits of Contextualization of Biblical Text Especial Parables in Africa}

There are lots of benefits those readers of contextualized gospel text in the African languages derives. These are:

- It can help those who are receiving the gospel to see it as their own as it addresses their own peculiar situation ${ }^{\text {xxix }}$

- When the gospel is duly contextualized, it will enable the message to confront what is wrong and sinful in the socio- cultural context that is being addressed.

- The suggestion of Whiteman ${ }^{x x x}$ stated that efforts made to contextualize the gospel message can potentially help the entire people within a community setting to have a deeper and corporate understanding of the gospel and its power.

It is also being suggested that as the gospel messages covers different cultural and linguistic barriers, contextualization could have help make the difference in its knowledge.xxi

It therefore means that any attempt to interpret the Bible outside the culture of the people in which the exegete intends to apply the Bible text, a cultural distance may be created and as such the text can be vogue.xxxii

\section{Conclusion}

The teaching/ story of the prodigal son was wrong in not reflecting the cultural situation of things in the host community. There are lots of good things that within both the Jewish culture and the African culture. Although, it is true that the Bible is seen as supra-cultural, while at the same time providing practical guidance and answers to the problem of life in every culture. However, the sieving of cultural ideologies with the Biblical truth is the major huddles African cultural seems to be suffering from. Serious attempt should be made to examine African cultural norms before they are been discarded in preference for Biblical truth.

\section{Recommendations}

Following recommendations

- Meaningful cultural norms are very important and should not be swept under the carpet

- When contextualization is given its rightful place in the cultural setting of the people, it will make them see the gospel as their own as it is addressed specifically to them.

- $\quad$ Properly contextualized text will enable the message to confront what is wrong and sinful in the affected socio-cultural context.

- $\quad$ It will also help to create a deepened and powerful understanding of the gospel

- $\quad$ To make Biblical translated versions for Africa to reflect true African identity.

\section{References}

i. Abogunrin,S.O.(2000a).Situation Theology as a Recipe for African Theological Exploration.

ii. African Journal of Biblical Studies 54: pp1-18.

iii. Anthony, Michael J. 2001, Introducing Christian Education. North Dartmouth, Massachusetts: Baker. p 117.

iv. Bailey, Kenneth E. 1973, The Cross and the Prodigal. St. Louis: Concordia, pp. 54-55.

v. Bediako. Kwame. 1995. Christianity in Africa: The Renewal of a Non-Western

vi. Religion. Maryknoll. N.Y.: Orbis

vii. Carson. D. A .. 1985 ed. a. Biblical interpretation and the church: The problem of contextualization. Nashville, Tenn.: Thomas Nelson.

viii. Charles H: 1979. The Church in culture: A dynamic equivalence model. In Gospel and culture: The papers of the consultation on the gospel and culture, ed. John Stott and Robert T. Coote, 285-312. Pasadena, Calif.: William Carey Library. Kraft, Charles H. 1999. Culture, world view and contextualization. In Perspectives on the world Christian movement: A reader, ed. Ralph D. Winter and Steven C.

ix. Hawthorne. 384-391. Pasadena: William Carey Library. Nufiez. Dyrness. William A. .(I 989a), learning about theology from the Third World.

x. Grand Rapids: Zondervan. (1990), Gilliland. Dean S. Contextual theology as incarnational mission. In The word among us: contextualizing theology for mission today, ed. Dean S. Gilliland, 9-31. Dallas, Texas: Word Publishing. pp9-31.

xi. Emilio A. 1985. The church in the liberation theology of Gustavo Gutierrez: 
xii. Description and Hermeneutical Analysis. In Biblical interpretation and the church:

xiii. The problem of contextualization, ed. D. A. Carson, 166-194. Nashville. Tenn::

xiv. Hesselgrave. David J. 1999 . Christian contextualization and biblical theology. In

xv. The relationship between epistemologv, hermeneutics, .biblical theology and contextualization. ed. Douglas Welker Kennard,. Lewiston. N.Y.:

xvi. Edwin Mellen. pp 153-1 80

xvii. Hiebert. Paul G. 1987. Critical contextualization. International Bulletin of

xviii. Missionary Research I L no. 3: 104-12

xix. Ijezie, L.E. 2007. The Biblical Text and Its Cultural Distance. Journal of Inculturation Theology 9:,

xx. $\quad$ Pp 3 - 18)

xxi. Adolf Julicher, ( 2013) Dictionary of the Bible, 2ed Oxford University Press

xxii. MacAuthur, 2011, The Master's Seminary Journal, Vol 22 (Spring), No 1 pp131-132.

xxiii. Mbite John M 1969, African Religions and Philosophy, New York Praeger ,p14.

xxiv. Microsoft ${ }^{\circledR}$ Encarta ${ }^{\circledR}$ 2009. (C) 1993-2008 Microsoft Corporation.

xxv. Richardson. Don. 1974. Peace child. Glendale. Calif.:

xxvi. Robert L. Plummer, 2009, "Parables in the Gospels: History of Interpretation and Hermeneutical

xxvii. Guidelines," Southern

xxviii. Baptist Journal of Theology 13, no. 3 (Fall):p 5.

xxix. Stabell, Timothy D. 2005, The modernity of witchcraft and theological contextualization in contemporary Africa. Ph.D. diss., Trinity International

xxx. University.

xxxi. Stephen B. 1992. Models of contextual theologv. Faith and Cultures. Mary knoll, N. Y.:

xxxii. Tienou. Tite. 1993,. Forming indigenous theologies. In Toward the 21 st century in

xxxiii. Christian mission: biblical, theological and historical foundations, ed. James

xxxiv. M. Phillips and Robert T. Coote , Grand Rapids: Eerdmans. pp 245-252.

xxxv. Thomas Nelson. Coe. Shoki. 1976. Contextualizing theology. In Third World theologies. ed. Gerald H. Anderson and Thomas F. Stransky. 19-24. New York

xxxvi. Walter, Tony interviewed by Bethel Jaja, April, 20 th , 2018.

xxxvii. Walls, Andrew F. .1996, The missionary movement in Christian history: Studies inthe transmission of the faith. Maryknoll, N.Y.: Orbis.

xxxviii. Wendland, Ernest R, 1996 "Finding Some Lost Aspects of Meaning in Christ's Parables of the

xxxix. Lost-And Found (Luke 15),” Trinity Journal 17:1 (Spring): 21.

xl. Whiteman, Darrell L. 1997. Contextualization: The theory, the gap, the challenge. international Bulletin of Missionary Research. 21, no. 1:2-

iErnest R. Wendland, "Finding Some Lost Aspects of Meaning in Christ's Parables of the Lost-And Found (Luke

15)," Trinity Journal 17:1 (Spring 1996): 21.

ii Wendland, p21

iii Adolf Julicher, Dictionary of the Bible, 2ed Oxford University Press (2013)

ivDyrness. William A. learning about theology from the Third World. Grand Rapids: Zondervan.(1990), Gilliland. Dean S. Contextual theology as incarnational mission. In The word among us: contextualizing theology for mission today, ed. Dean S. Gilliland, 9-31. Dallas, Texas: Word Publishing.(I 989a),pp9-31.

v Taber, 1991 p3\&p8.

vi Taber 88

viiRobert L. Plummer, "Parables in the Gospels: History of Interpretation and Hermeneutical Guidelines," Southern

Baptist Journal of Theology 13, no. 3 (Fall 2009): p 5.

viii Plemmer, p5

ix Adolf, 2013

x Detronomy 21:18-21

xiJohn MacAuthur, The Master's Seminary Journal, Vol 22 (Spring 2011), No 1 pp131-132.

xi MacAuther, 2011 p132.

xii J MacAuthur, The Master's Seminary Journal, Vol 22 (Spring 2011), No 1 pp131-132.

xiii MacAuther, $2011 \mathrm{p} 132$.

xiv Deut, 21:18-21

xvBailey, Kenneth E. The Cross and the Prodigal. St. Louis: Concordia, 1973, pp. 54-55.

xvi Bailey, p55

xvii Ibid, p55

xviiiHesselgrave. David J. Christian contextualization and biblical theology. In

The relationship between epistemologv, hermeneutics, biblical theology and contextualization. ed. Douglas Welker Kennard, Lewiston. N.Y.

Edwin Mellen.1999 pp 153-1_80

xixCarson. D. A. ed. a. Biblical interpretation and the church: The problem of contextualization. Nashville, Tenn.: Thomas Nelson.1985

xxStabell, Timothy D. The modernity of witchcraft and theological

contextualization in contemporary Africa. Ph.D. diss., Trinity International

University.2005

xxi Mbite John M African Religions and Philosophy, New York Praeger 1969, p14.

xxii Mbite, p14. 
xxiiiAbogunrin, S.O. (2000a). Situation Theology as a Recipe for African Theological Exploration. African Journal of Biblical Studies 54:(2000a pp1-18. xxivAnthony, Michael J. Introducing Christian Education. North Dartmouth, Massachusetts: Baker,2001, p 117.

xxv Anthony, p117

xxvi Ibid, p118

xxvii Tony Walter, interviewed by Bethel Jaja, April, 20th 2018.

xxvii Walter, April, $20^{\text {th }} 2018$.

xxixTienou. Tite. Forming indigenous theologies. In Toward the 21 st century in

Christian mission: biblical, theological and historical foundations, ed. James

M. Phillips and Robert T. Coote, Grand Rapids: Eerdmans1993 pp 245-252.

xxxWhiteman, Darrell L. 1997. Contextualization: The theory, the gap, the challenge.

international Bulletin of Missionary Research (1997) 21, no. 1: 2-

xxxiWalls, Andrew F.The missionary movement in Christian history: Studies in

the transmission of the faith. Maryknoll, N.Y.: Orbis.1996

xxxii Ijezie, L.E. The Biblical Text and Its Cultural Distance. Journal of Inculturation Theology 9: 2007, Pp 3 - 18) 